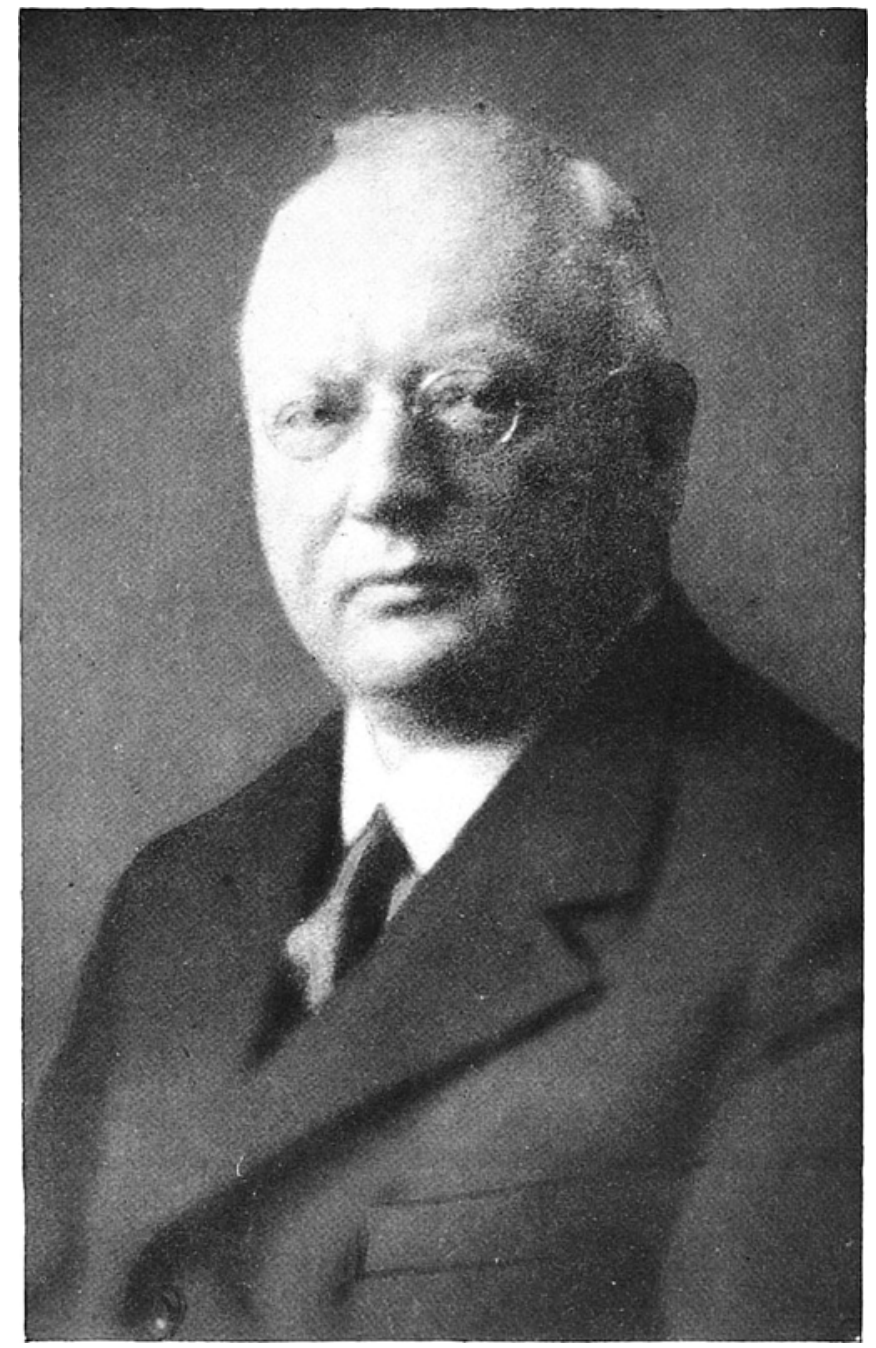

I Prof, Dx, IN. SOHNGEN. 


\section{In Memoriam Prof. Dr. Ir. N. L. Söhngen.}

Den 24sten December 1934 overleed Prof. Dr. N. L. Söhngen, in leven hoogleeraar aan de Landbouwhoogeschool te Wageningen. Na een ernstige ziekte van 10 weken, waarvan het verloop zich echter alleszins gunstig liet aanzien, werden wij door een plotseling verergeren van den toestand opgeschrikt en slechts korten tijd daarna bereikte ons het bericht van zijn overlijden. Den 28sten December waren wij aanwezig bij zijn crematie te Westerveld, waar vele vrienden en vereerders hem de laatste eer bewezen. Prof. Dr. P. Verkade gaf in eenvoudige woorden een treffende schets van Söhngen als mensch en als denker. Zijn groote menschelijkheid, zijn losheid van conventie, zijn originaliteit, zijn toegewijde liefde bij de beoefening van wetenschap en kunst stempelden hem tot een mensch van grooten stijl. Zelfs oppervlakkige kennismaking deed hem reeds als zoodanig herkennen. Door zijn kunnen was hij tevens een geniaal mensch.

Nicolaas Louis Söhngen werd in 1878 te Oirschot geboren, hij bezocht de Rijks hoogere burgerschool te Veendam en studeerde van 1898 tot 1902 aan de Polytechnische school te Delft voor scheikundig ingenieur. Voor zijn leermeester Prof. Dr. S. Hoogewerff, op wiens laboratorium hij gedurende de jaren 1902 tot 1904 assistent was, had hij een zeer hooge vereering. Daarna van 1904 tot 1906 werkte hij in het microbiologisch laboratorium te Delft onder leiding van Beyerinck, bij wien hij in 1906 promoveerde op een proefschrift getiteld: "Het ontstaan en verdwijnen van waterstof en methaan onder den invloed van het organische leven" (Juli 1906). Reeds van tevoren verscheen van hem een publicatie "Over bacteriën, welke methaan als koolstofvoedsel en als energiebron gebruiken" (Kon. Akad. v. Wetenschappen 1905).

$\mathrm{Na}$ zijn promotie was hij van 1906 tot 1908 verbonden aan 
de margarinefabrieken van de Firma Verschuere en Co. te Rotterdam en van 1908 tot 1912 aan de margarinefabriek van den heer M. P. A. Proos te Middelburg. Uit deze periode dateeren een aantal publicaties op verschillend gebied n.l.:

Over ureumsplitsing bij afwezigheid der eiwitten (Kon. Akad. v. Wet., Amsterdam 1908),

Vetsplitsing door bacteriën, (idem Dec. 1910),

Microben lipase, idem Dec. 1910.

Thermotolerante lipase, idem Apr. 1911.

Van deze 3 publicaties werd in den len band van Folia microbiologica nog een samenvatting in de Duitsche taal gegeven:

Ueber Fettspaltende Mikroben und deren Einflusz auf Molkereiproducte und Margarine.

En hiermee deed Söhngen zijn intrede in de pas opgerichte Nederlandsche Microbiologische Vereeniging. Het was op de eerste vergadering dezer vereeniging, dat hij een voordracht over dit onderwerp hield. Op eenvoudige wijze kon door de vetbuisjesmethode het vermogen van anaerobe en aerobe microörganismen om vet te splitsen worden aangetoond. Interessant is de thermotolerante lipase, die kookhitte verdraagt en afgescheiden wordt door trypsine-vormende vetsplitsende bacteriën.

Ondertusschen vond Söhngen nog tijd om samen met Prof. Dr. G. van Iterson onderzoekingen te verrichten omtrent geconstateerde aantasting van het z.g. Manbarklak. Een rapport hierover verscheen in het Weekblad „De Ingenieur” van 18 Maart 1911.

In 1912 keerde Söhngen naar Delft terug, waar hiji tot 1915 in het laboratorium van Beyerinck als assistent werkte. In 1913 verscheen een publicatie over "Oxydatie van petroleum, paraffine, paraffineolie en benzine door microben" (Kon. Akad. van Wetensch., 13 Mrt. 1913, Centralbl. II Bd 37, 1913). Deze mededeeling werd zeer snel gevolgd door een publicatie over de „Einflusz von Kolloiden auf mikrobiologische Prozesse" (Centralbl. II Bd 38, 1913). Een groot aantal processen wordt versneld door aanwezigheid van kolloïden (kiezelzuur, turf, filtreerpapier etc.) in de vloeibare voedingsbodems. Zoo wordt o.a. de stikstofbinding door Azotobacter chroöcoccum belangrijk bevorderd door aanwezigheid van kolloidaal $\mathrm{Si} \mathrm{O}_{2}$. Turf, filtreer- 
papier, bloedkool en tuingrond werken versnellend op de alkoholgisting (zie ook Folia mikrobiologica Jahrg. 2 Heft 1). Ook werd de invloed van humus, kolloïdaal kiezelzuur, ijzerhydroxyde en aluminiumhydroxyde, bloedkool en filtreerpapier op de amylumsplitsing, de azijnbacteriën, de ureumsplitsing, de denitrificatie, de nitrificatie en de petroleum oxydatie nagegaan.

In Folia mikrobiologica III (1914) vinden we vervolgens een mededeeling getiteld „Ueber reduzierende Eigenschaften der Essigbakterien" (medegedeeld op een der vergaderingen van onze vereeniging). Het bleek, dat azijnbacteriën, die normaal uit alkohol azijnzuur vormen, ook tot het omgekeerde proces in staat zijn; echter ook uit glucose, Ca-gluconaat en andere zouten van organische zuren werden geringe hoeveelheden alkohol gemaakt.

Met J. G. Fol publiceerde Söhngen een artikel in het Centralbl. f. Bakt. II Bd. 40 (1914) over „Die Zersetzung des Kautschucks durch Mikroben. Twee Actinomyces-soorten werden beschreven, $A$. elastica en $A$. fuscus, die de rubber aantasten.

Zijn belangstelling voor den invloed van kolloïden op microbiologische processen was aanleiding dat Söhngen zich bezig ging houden met het maken van kolloïdale oplossingen. Zoo nam hij o.a. ook de bereiding van kolloïdale koolstof in studie. Het resultaat hiervan was een publicatie in het "Chemisch Weekblad" van 1914: "Kolloïdaal opgeloste en gelatineuze koolstof".

In hetzelfde jaar verscheen een uitgebreid verslag over het onderzoek naar de oorzaken van het ontstaan van den stank der Haagsche grachten en aanwijzingen betreffende middelen ter verbetering. Het jaar 1914 was bijzonder productief. In het Centralbl. f. Bakt. Abt. II Bd. 40 verscheen nog: „Umwandlungen von Manganverbindungen unter dem Einflusz mikrobiologischer Prozesse. In alkalisch milieu worden mangano-zouten omgezet tot mangani-oxyden. Bij de aerobe cellulose aantasting ontstaan oxyzuren, die de mangani-verbindingen overvoeren in oplosbare manganozouten. Deze vorming van oxyzuren uit cellulose is de oorzaak, dat Azotobacter met cellulose als koolstofbron in ruwculturen zich goed kan ontwikkelen. Dit onderzoek bracht Söhngen in contact met de Veenkoloniale haverziekte, een bodemziekte, die door geringe hoeveelheden mangaansulfaat kan genezen worden. 
In 1915 volgde nu de benoeming tot directeur van de Microbiologische Afdeeling van het Rijkslandbouwproefstation in Groningen. Hier werd hem het vraagstuk der Veenkoloniale haverziekte voorgelegd. Deze bodemziekte, die in de Groninger Veenkoloniën en ook elders op alkalisch bemeste zand- en veengronden optreedt, is met geringe hoeveelheden mangaansulfaat te bestrijden. Een tegenhanger van deze ziekte is de z.g. Hooghalensche ziekte, die zich juist op zure gronden voordoet. Met behulp van Azotobacter culturen kon de zuurgraad van den grond getitreerd worden en het percentage daarin aanwezig vrij humuszuur worden bepaald. Beter ging dit met behulp van een indicator-methode, door diffusie van grondsuspensies in met indicatoren gekleurde agar-agar. Het bleek, dat de Veenkoloniale haverziekte slechts voorkwam op gronden waar de humuszuren geheel verzadigd waren, terwijl tevens nog een overschot aan alkali aanwezig was. De Hooghalensche ziekte daarentegen trad slechts op, wanneer meer dan $50 \%$ van het humuszuur in vrijen toestand aanwezig was. (N. L. Söhngen, A. Kneteman en K. T. Wieringa, Bepaling van het gehalte aan vriie en gebonden humus in zand en veengronden. Versl. van Landbouwkundige onderzoekingen der Rijkslandbouwproefstations XXI 1917).

Toen Söhngen in 1917 in Wageningen tot hoogleeraar werd benoemd, was daar geen gelegenheid om het onderwijs in de microbiologie op behoorlijke wijze te geven. Wel was er een woonhuis als laboratorium ingericht, maar hier was geen gelegenheid voor het geven van colleges en practica. De bouw van een nieuw laboratorium werd echter door den minister beloofd, terwijl gelden beschikbaar werden gesteld voor de aanschaffing van den noodigen inventaris. Met zijn gewone voortvarendheid trok Söhngen aanstonds aan den arbeid om met de toegezegde middelen te komen tot een modern ingericht laboratorium, dat ook in de toekomst zou kunnen voorzien in de behoefte aan de Landbouwhoogeschool en in den herfst van 1919 werd vooi den bouw de eerste spa in den grond gestoken. Wat dit aan schrijven en confereeren, meten en opnemen, geduld oefenen en afwachten een tijd gekost heeft is niet te beschrijven. Eindelijk kwam in 1922 het nieuwe gebouw gereed en kon het onderwijs in de microbiologie aan de landbouwhoogeschool, dat van onder af moest worden opgebouwd pas goed een aanvang 
nemen. Het laboratorium is ingedeeld in twee deelen, waarvan een voor colleges en candidaatspractica bestemd is en het andere voor eigen onderzoekingen, voor laboranten, die gedurende de ingenieursstudie aan speciale onderwerpen komen werken en voor promovendi. Bij het laboratorium ligt eenı proeftuin, met perceelen van verschillende bemestingstoestand en zuurgraad, zoodat voor de practica steeds biologisch uiteenloopend materiaal aanwezig is. De voor proefnemingen minder geschikte overblijvende strooken en randen wist Söhngen dusdanig op te vullen, dat een harmonisch geheel ontstond, geheel overeenkomstig zijn aard. Aan de hooge opvatting, die Söhngen van zijn taak had, waarvan hij getuigde in de rede uitgesproken bij de aanvaarding van het hoogleeraarsambt, heeft hij trouw vastgehouden. Zijn colleges en publicaties getuigen hiervan. Zijn onderzoekingen hadden plaats op zuiver wetenschappelijk gebied, terwijl hij als lid van den octrooiraad en als lid van de commissie van advies omtrent de landbouwkundige aangelegenheden betreffende de drooggekomen Zuiderzeegronden voortdurend met vraagstukken uit de practijk in aanraking kwam. Ook van andere zijde werd uit de practijk dikwijls zijn advies ingewonnen.

De officieele opening van het nieuwe laboratorium viel samen met de herdenking van den geboortedag van Louis Pasteur op 27 Dec. 1822-1922. De Microbiologische Vereeniging vergaderde toen in Wageningen. De woorden van Pasteur, waarmee hij zijn herdenkingsrede besloot, waren geheel in zijn geest: „La science dans notre siècle est l'âme de la prosperité des nations et la source vive de tout progrès. Sans doute la politique avec ses fatiguantes et quotidiennes discussions semble être notre guide. Vaine apparence. Ce qui nous mène ce sont quelques découvertes scientifiques et leurs applications. L'avenir appartient à la science. Malheur aux peuples qui fermeraient les yeux sur cette verite".

Van zijn publicaties noem ik nog de volgende:

P. E. Verkade en N. L. Söhngen. De aantasting van cistransisomere onverzadigde zuren door schimmeis. (Kon. Akad. v. Wetensch. Dl. XXVIII en Centralbl. f. Bakt. II Bd. 50, 1922).

N. L. Söhngen en C. Coolhaas. De vergistintg van galactose door Sacch. cerevisiae. (Tijdschr. v. vergelijkende geneesk. enz. Dl IX, 1922). 
P. C. Gerretsen, A. Grijns, J. Sack, N. L. Söhngen. Das Vorkommen eines Bakteriophagen in den Wurzelknöllchen der Leguminosen (Centralbl. f. Bakt. II Bd. 60, 1923).

N. L. Söhngen en W. S. Smith. De invloed van de temperatuur op de ontleding van waterstofperoxyd door persgist. (Tijdschr. v. vergelijkende geneeskunde enz. D1 X, 1923).

N. L. Söhngen en C. Coolhaas. Der Einflusz ultravioletten Lichts auf die Alkoholgährung. (Wochenschrift für Brauerei $\mathrm{XL}$ ).

N. L. Söhngen en A. Griins. Over de afsterving van den bacteriophaag van Bacillus Danicus. (Kon. Akad. v. Wetensch. XXXIV, No. 8).

N. L. Söhngen en K. T. Wieringa. Permeabiliteitsbepalingen met Saccharomyces cerevisiae. (Kon. Akad. van Wetensch. DI XXXVI, No. 10, 1928).

In het studiejaar 1928-1929 was Söhngen Rector-magnificus der Landbouwhoogeschool. Zijn denkbeelden over het wezen van den bacteriophaag zette hij toen uiteen in zijn rede op 9 Mrt. 1929 ter gelegenheid van den 1len verjaardag der Landbouwhoogeschool. Door het vinden van basteriën, die in hun voeding uitsluitend aangewezen zijn op andere bacteriën, - de bacteriophagie is dus niet beperkt tot den bacteriophaag - was zijn meening dat de bacteriophaag als een levend organisme op te vatten is, belangrijk versterkt. N. L. Söhngen, Heterobacteriolyse en Bacteriophagie (Kon. Akademie van Wetenschappen Dl XXXVI, No. 10). Velen onzer zullen zich de discussies nog herinneren, die op een vergadering van de Nederlandsche Microbiologische vereeniging gevoerd werd, naar aanleiding van de onderzoekingen van Den Dooren de Jong over het produceeren van den bacteriophaag door bepaalde stammen van B. megatherium, (Verg. Ned. Microbiologische Vereeniging). Ofschoon Söhngen de proeven van Den Dooren de Jong ten volle bevestigen kon, was hij niet overtuigd van de juistheid der interpretatie.

In de laatste jaren van zijn leven heeft Söhngen zich nog in het bijzonder geinteresseerd voor het probleem der mitogenetische stralen. De vele proeven hierover in zijn laboratorium genomen, gaven geen overtuigende resultaten over het bestaan van een mitogenetisch effect.

De beteekenis van het experiment stelde Söhngen ver 
boven die van theoretische beschouwingen. Deze kunnen slechts dienen om richting te geven aan het onderzoek. Slechts wat door maat en gewicht als resultaat van de proef is vastgelegd heeft blijvende waarde.

Het noodlot heeft gewild, dat Söhngen's laatste werk over het verdwijnen van waterstof onder invloed van microben geheel bij zijn eerste onderzoek aansluit. Helaas heeft hij dit niet kunnen voltooien. Het onderzoek is echter zoover gevorderd, dat op de bereikte resultaten kan worden voortgebouwd.

Veel te vroeg is Söhngen gestorven, voor zijn gezin, voor zijn werk, voor de landbouwhoogeschool. Zij, die het voorrecht hadden hem van nabij te kennen kunnen niet genoeg de rijkdom waardeeren, die hun leven door omgang met hem heeft gekregen.

K. T. WIERINGA. 